ANALYTICAL METHODS, Accepted 19th March 2017

DOI: $10.1039 / \mathrm{c} 7 \mathrm{ay} 00126 \mathrm{f}$

\title{
A comparison of colorimetric assays detecting hydrogen peroxide in leaf extracts
}

Anikó Mátai and Éva Hideg*

Department of Plant Biology, Faculty of Sciences, University of Pécs,

Ifjúság u. 6, H-7624 Pécs Hungary

\begin{abstract}
Hydrogen peroxide $\left(\mathrm{H}_{2} \mathrm{O}_{2}\right)$ is a central molecule in plant stress responses as potential oxidizing agent or signal molecule, depending on its localization and cellular concentrations. The present work compared three colorimetric assays assessing $\mathrm{H}_{2} \mathrm{O}_{2}$ concentrations in terms of sensitivity, linearity with increasing $\mathrm{H}_{2} \mathrm{O}_{2}$ concentrations, solvent interactions and recovery of exogenous $\mathrm{H}_{2} \mathrm{O}_{2}$ from leaf extracts. The tested methods were based on the oxidation of one of the following chromophores: potassium iodide (KI), 3,3'-diaminobenzidine (DAB) or xylenol orange (XO). Various solvents were chosen for extraction to represent two different approaches of sampling: extraction into water or water-based buffer providing material for an array of bioassays; and extraction into solutions containing trichloroacetic acid (TCA) or ethanol in order to minimize interactions arising from leaf biochemistry. The most employable technique was the xylenol orange assay in organic solvents, although it is advisable to interpret results against a series of spiked samples rather than a calibration line acquired in solvent only.
\end{abstract}

\section{Introduction}

Hydrogen peroxide $\left(\mathrm{H}_{2} \mathrm{O}_{2}\right)$ is a reactive oxygen species (ROS) generated in a variety of cellular compartments including chloroplasts, mitochondria, peroxisomes and cell walls [1]. $\mathrm{H}_{2} \mathrm{O}_{2}$ concentrations in leaves vary strongly between and within species and are also affected by age and physiological status [2]. $\mathrm{H}_{2} \mathrm{O}_{2}$ sources include enzymes, such as superoxide dismutases, nicotinamide adenine dinucleotide phosphate oxidases and cell wall peroxidases, as well as non-enzymatic processes, for example the spontaneous conversion of superoxide radicals to $\mathrm{H}_{2} \mathrm{O}_{2}$ or glycolate oxidation in peroxisomes [3]. Among ROS, $\mathrm{H}_{2} \mathrm{O}_{2}$ is the least reactive and has the longest lifetime, approximately $1 \mathrm{~ms}$ in soybean (Glycine max L.) cell suspension cultures [1] or in HeLa cell cultures [4]. $\mathrm{H}_{2} \mathrm{O}_{2}$ is assumed to diffuse some $\mu \mathrm{m}$ from its production site [5] and even cross membranes via aquaporins [6]. Because of these characteristics, $\mathrm{H}_{2} \mathrm{O}_{2}$ is considered as a signaling molecule in growth and development [7], cell cycle [8], flowering [9], senescence [10] and in stress responses [11]. On the other hand, travelling $\mathrm{H}_{2} \mathrm{O}_{2}$ may spread oxidative damage as the source of highly reactive hydroxyl radicals via Fenton chemistry [12] or direct photo-cleavage by UV-B [13]. Consequently, assessing $\mathrm{H}_{2} \mathrm{O}_{2}$ concentrations in leaves is of special interest as indicator of physiological status and stress responses.

Various methods are available to measure the concentration of $\mathrm{H}_{2} \mathrm{O}_{2}$ in plant samples, for example fluorescence [14], chemiluminescence [15], electrochemical [16] or colorimetric [2] assays. Although results may be affected by metabolites other than 
$\mathrm{H}_{2} \mathrm{O}_{2}$, and appear to depend on the choice of method [17, 18], photometric assays based on absorption changes of chromophores upon oxidation by $\mathrm{H}_{2} \mathrm{O}_{2}$ are still the most widely used techniques due to their simplicity, low cost and rapidity. Probably the most popular assays are the ones using KI [19], DAB [20] or XO [21].

We compared these methods in three steps, in order to examine: (i) the absorption characteristics of the oxidized chromophores, (ii) the concentration range of $\mathrm{H}_{2} \mathrm{O}_{2}$ detection, (iii) whether leaf metabolites other than $\mathrm{H}_{2} \mathrm{O}_{2}$ interfered with the assay. For the last step, leaf extracts were spiked with exogenous $\mathrm{H}_{2} \mathrm{O}_{2}$ which was attempted to recover using the assays. All measurements were repeated using four different solvents: distilled water, potassium-phosphate buffer, trichloroacetic acid (TCA) or ethanol. Solvents were chosen to represent two different approaches in sampling. One is to preserve biological activities and prepare extracts using a $\mathrm{pH}$ neutral water-based buffer [22] or distilled water [23]. The advantage of these methods is that extracts are also suitable for determinations of various enzyme activities or pigment concentrations. The disadvantage is that biological activities maintained in such extracts may modify metabolite profiles during extraction. For example, peroxidases may decrease $\mathrm{H}_{2} \mathrm{O}_{2}$ concentrations. Such interference can be prevented by inactivating biological functions during extraction, for example by the use of TCA [24] or alcohol: water solutions that are frequently applied to study phenolic compounds [25]. This second approach, however, may hinder assays relying on using exogenous enzymes to catalyze chromophore oxidation by $\mathrm{H}_{2} \mathrm{O}_{2}$.

\section{Materials and methods}

\section{$\mathrm{H}_{2} \mathrm{O}_{2}$ determination}

$1 \mathrm{M} \mathrm{KI}, 3.5 \mathrm{mM}$ DAB and $125 \mu \mathrm{M}$ XO solutions were prepared as described [19-21]. For absorption characterization and $\mathrm{H}_{2} \mathrm{O}_{2}$ concentration range determination tests, a series of 1-100 $\mathrm{nM} \mathrm{H}_{2} \mathrm{O}_{2}$ solutions were dissolved in $100 \mu \mathrm{L}$ total volume of distilled water, $100 \mathrm{mM}$ K-phosphate buffer ( $\mathrm{pH} 7.0), 70 \%(\mathrm{v} / \mathrm{v})$ ethanol or $6 \%(\mathrm{v} / \mathrm{v})$ TCA and $1 \mathrm{~mL}$ of KI, DAB or XO solution were added. For leaf compound interference test, $100 \mu \mathrm{L}$ of leaf extract (see below) was added to $1 \mathrm{~mL}$ of chromophore solution. The DAB assay was performed with the use of $0.4 \mathrm{U}$ horseradish peroxidase (HRP).

\section{Plant material and leaf extract preparation}

Our choice of model plant, Nicotiana benthamiana is widely applied in plant virology [26] where responses to infection reportedly include increased cellular $\mathrm{H}_{2} \mathrm{O}_{2}$ concentrations [27]. Plants were grown in growth chambers (Sanyo MLR-352H-PE, Panasonic Healthcare Co., Ltd., Oizumi, Japan) under $90 \mu \mathrm{mol} \mathrm{m}{ }^{-2} \mathrm{~s}^{-1}$ PAR $(16 \mathrm{~h} / 8 \mathrm{~h}$ light/dark, $25^{\circ} \mathrm{C} / 20^{\circ} \mathrm{C}, 70 \%$ humidity). Freshly harvested leaves from 4 weeks old plants were homogenized in ice cold solvent (one of the above) using pestle and mortar. Extracts were centrifuged $\left(15,000 \times g, 10 \mathrm{~min}, 4^{\circ} \mathrm{C}\right.$ ) (Heraeus Fresco 17 Centrifuge, Thermo Fisher Scientific Inc., Waltham, MA, USA) and supernatants were used immediately. 


\section{Results and discussion}

\section{Absorption characteristics}

Chromophore oxidation by $\mathrm{H}_{2} \mathrm{O}_{2}$ should be accompanied by a characteristic absorption change. Leaf samples contain a plethora of metabolites absorbing UV and/or visible light and concentrations of these may vary in response to the same environmental conditions which are expected to modify $\mathrm{H}_{2} \mathrm{O}_{2}$ levels. A well-defined peak in the absorption spectrum of the oxidized chromophore is necessary to separate $\mathrm{H}_{2} \mathrm{O}_{2}$ induced changes from background absorption from other metabolites. The product of the $\mathrm{KI}$ and $\mathrm{H}_{2} \mathrm{O}_{2}$ reaction (triiodide, $\mathrm{I}_{3}{ }^{-}$) has maximum absorption at 352 $\mathrm{nm}$, although the assay is usually evaluated using $390 \mathrm{~nm}$ data [19]. This peak was detected in pure water, in the water based phosphate buffer and in ethanol but not in TCA solution. Consequently, the KI assay in TCA was not included in further analyses (Table 1). The absorption maximum of oxidized DAB was detected at 465 $\mathrm{nm}$ in water, in K-phosphate buffer and in ethanol; and at $455 \mathrm{~nm}$ in acidic TCA solution (Table 1). The chemically unknown colored product of the reaction between $\mathrm{XO}$ and $\mathrm{H}_{2} \mathrm{O}_{2}$ had a maximum absorption at $560 \mathrm{~nm}$ in all tested solvents (Table 1). This absorption is seems ideal for assessing $\mathrm{H}_{2} \mathrm{O}_{2}$ in chlorophyll containing samples which have low absorption in this spectral region themselves. On the other hand, near $\mathrm{UV}$ and blue absorptions of oxidized $\mathrm{KI}$ and $\mathrm{DAB}$, respectively, are to be measured over the background of pigments, such as chlorophyll or flavonoids.

\section{Detectable $\mathrm{H}_{2} \mathrm{O}_{2}$ concentration range}

Increase in the chromophore's absorption is required to be linear with increasing $\mathrm{H}_{2} \mathrm{O}_{2}$ concentrations for a valid quantification. Ranges of $\mathrm{H}_{2} \mathrm{O}_{2}$ concentrations fulfilling this requirement are listed in the second row of Table 1 . When applicable, the assays were sensitive to $\mathrm{H}_{2} \mathrm{O}_{2}$ concentrations as low as $1 \mathrm{nM}$. The DAB-based assay had the widest calibration range (up to $80 \mathrm{nM}$, Table 1) but was not applicable in TCA solution due to the non-linearity of calibration (Supplementary Information). In the ethanol: water solution, DAB was less responsive to low $\mathrm{H}_{2} \mathrm{O}_{2}$ concentrations. The same solution, however, expanded the calibration range of the KIbased assay, as compared to that in water or buffer (Table 1). The relatively narrow 1$10 \mathrm{nM}$ linear response range of the XO-based assay (slightly wider than the 1-8 $\mathrm{nM}$ recommended by the manufacturer [21]) calls for caution when samples with high $\mathrm{H}_{2} \mathrm{O}_{2}$ concentrations are evaluated.

\section{Interference with leaf compounds}

Metabolites present in leaf extracts should not interfere with the rate of chromophore oxidation by $\mathrm{H}_{2} \mathrm{O}_{2}$, i.e. should not modify the linearity of the above calibrations. This requirement was only examined in solvents in which calibration was possible (row-(ii) in Table 1). Leaf samples were spiked with various amounts of $\mathrm{H}_{2} \mathrm{O}_{2}$ during preparation and measuring the efficiency of detecting this exogenous $\mathrm{H}_{2} \mathrm{O}_{2}$. Spiking was only possible in TCA and ethanol solutions. All three methods failed to respond to exogenous $\mathrm{H}_{2} \mathrm{O}_{2}$ in the presence of leaf extracts in water or buffer. This may be explained by the consumption of added $\mathrm{H}_{2} \mathrm{O}_{2}$ by leaf antioxidants. Neither the KI- nor the DAB-based assay responded to 
spiking in the ethanol solution, (Electronic Supplementary Information, Fig. S4). However, when applying the XO assay in organic solvents, spiked samples showed linear increase in $560 \mathrm{~nm}$ absorption with increasing exogenous $\mathrm{H}_{2} \mathrm{O}_{2}$ in both TCA and ethanol solutions (Fig. 1).

\section{Correction of the XO assay}

The two fitting lines characterizing the connections between added and recovered $\mathrm{H}_{2} \mathrm{O}_{2}$ concentrations in TCA and ethanol solutions were different from each other and also from the ideal line corresponding to equality (dashed line in Fig. 1.). Both had non-zero intercepts and their slopes were ether higher (TCA) or lower (ethanol) than that of the equality line. The positive intercepts correspond to the $\mathrm{H}_{2} \mathrm{O}_{2}$ contained in the leaf extract that was relatively low because the model plants were not exposed to stress. However, the $\mathrm{XO}$ method evaluated leaf $\mathrm{H}_{2} \mathrm{O}_{2}$ contents differently, as 1.0 or $2.8 \mathrm{nM}$ (per $100 \mathrm{mg}$ fresh weight), when measured in TCA or in ethanol, respectively. This discrepancy may be explained by assuming that extracting into different solvents resulted in samples containing different amounts of phenolic compounds and ascorbate that may react with $\mathrm{H}_{2} \mathrm{O}_{2}$ during sample preparation and thus affect detection [17].

As endogenous $\mathrm{H}_{2} \mathrm{O}_{2}$ adds to exogenous concentrations, ideal recovery of spiking concentrations is expected to shift fitting lines upwards but keeping a slope equal or close to 1 . This was not the case in our experiment. Detected $\mathrm{H}_{2} \mathrm{O}_{2}$ concentrations were all higher than spiking concentrations but slopes were 1.24 and 0.84 when the XO assay was applied in $6 \%$ TCA or in $70 \%$ ethanol, respectively (Fig. 1). In addition to the applied solvent, the extent of over- or underestimating depended on $\mathrm{H}_{2} \mathrm{O}_{2}$ concentrations. These results indicate that it is not advisable to rely on a single spiking concentration as reference. Statistical analysis of the two assay conditions as comparison of methods confirmed significant differences (Electronic Supplementary Information, Fig. S5 and Table S1).

\section{Conclusions}

Our results show that among the tested conditions extraction into and assaying in TCA or ethanol with XO as chromophore proved the most suitable methods to detect $\mathrm{H}_{2} \mathrm{O}_{2}$ in plant derived samples. However, it is recommended to calculate cellular concentration relying on a series of $\mathrm{H}_{2} \mathrm{O}_{2}$ spiked samples rather than a calibration line acquired in the corresponding solvent only.

\section{Acknowledgements}

This work was supported by the Hungarian Scientific Research Fund (grant number OTKA K112309).

The present scientific contribution is dedicated to the 650th anniversary of the foundation of the University of Pécs, Hungary. 


\section{References}

1 S. S. Gill and N. Tuteja, Plant Physiol. Biochem., 2010, 48, 909-930.

2 J. M. Cheeseman, J. Exp. Bot., 2006, 57, 2435-2444.

3 L. Niu and W. Liao, Front. Plant Sci. 2016, 7, 230.

4 J. B. Lim, B. K. Huang, W. M. Deen and H. D. Sikes, Free. Radic. Biol. Med., 2015, 89, 47-53.

5 F.-J. Schmitt, G. Renger, T. Friedrich, V. D. Kreslavski, S. K. Zharmukhamedov, D. A. Los, V. V. Kuznetsov and S. I. Allakhverdiev, Biochim. Biophys. Acta, 2014, 1837, 835-848.

6 G. P. Bienert, A. L. Moller, K. A. Kristiansen, A. Schulz, I. M. Moller, J. K. Schjoerring and T. P. Jahn, J. Biol. Chem., 2007, 282, 1183-1192.

7 J. Foreman, V. Demidchik, J. H. Bothwell, P. Mylona, H. Miedema, M. A. Torres, P. Linstead, S. Costa, C. Brownlee, J. D. Jones, J. M. Davies and L. Dolan, Nature, 2003, 422, 442-446.

8 R. Mittler, S. Vanderauwera, M. Gollery and F. Van Breusegem, Trends Plant Sci., 2004, 9, 490-498.

9 J. Liu, D. Macarisin, M. Wisniewski, Y. Sui, S. Droby, J. Norelli and V. Hershkovitz, Plant Pathol.,2013, 62, 820-828.

10 C. L. Peng, Z. Y. Ou, N. Liu and G. Z. Lin, Rice Sci., 2005, 12, 179-186.

11 K. Apel and H. Hirt, Annu. Rev. Plant Biol., 2004, 55, 373-399.

12 B. L. Upham and L. S. Jahnke, Photosynth. Res., 1986, 8, 235-247.

13 Gy. Czégény, M. Wu, A. Dér, L.A. Eriksson, Å. Strid and É. Hideg, FEBS Lett., 2014, 588, 2255-2261.

14 B. Tang and Y. Wang, Spectrochim. Acta A, 2003, 59, 2867-2874.

15 S. Lu, J. Song and L. Campbell-Palmer, Sci. Hortic., 2009, 120, 336-341.

16 K. Jiao and W. Sun, Microchem. J., 2002, 72, 123-130.

17 S. Veljovic-Jovanovic, G. Noctor and C. H. Foyer, Plant Physiol. Biochem., 2002, 40, 501-507.

18 G. Queval, J. Hager, B. Gakière and G. Noctor, J. Exp. Bot., 2008, 59, 135-146.

19 V. Velikova, I. Yordanov and A. Edreva, Plant Sci., 2000, 151, 59-66.

I. Śnyrychová, F. Ayaydin and É. Hideg, Physiol. Plant., 2009, 135, 1-18.

20 https://www.sigmaaldrich.com/content/dam/sigmaaldrich/docs/Sigma/Bulletin/pd1bul.pdf

21 L. Mejía-Teniente, F. D. Durán-Flores, A. M. Chapa-Oliver, I. Torres-Pacheco, A. Cruz-Hernández, M. M. González-Chavira, R. V. Ocampo-Velázquez and R. G. Guevara-González, Int. J. Mol. Sci., 2013, 14, 10178-10196.

22 H. W. Choi, Y. J. Kim, S. C. Lee, J. K. Hong and B. K. Hwang, Plant Physiol., 2007, 145, 890-904.

23 S. Junglee, L. Urban, H. Sallanon and F. Lopez-Lauri, Am. J. Anal. Chem., 2014, 5, 730-736.

24 K. Csepregi, S. Neugart, M. Schreiner, and É. Hideg, Molecules, 2016, 21, 208.

25 Y. Li, H. Cui, X. Cui and A. Wang, Curr. Opin. Virol. 2016, 17, 19-24.

26 H. Yoda, K. Fujimura, H. Takahashi, I. Munemura, H. Uchimiya and H. Sano, Plant. Mol. Biol. 2009, 70, 103-112. 
Table 1.

Comparison of $\mathrm{H}_{2} \mathrm{O}_{2}$ detecting colorimetric assays

\begin{tabular}{|l|c|c|c|c|c|c|c|c|c|c|c|c|}
\cline { 2 - 13 } \multicolumn{1}{c|}{} & \multicolumn{4}{c|}{ KI } & \multicolumn{4}{c|}{ DAB } & \multicolumn{4}{c|}{ XO } \\
\cline { 2 - 13 } \multicolumn{1}{c|}{} & water & buffer & EtOH & TCA & water & buffer & EtOH & TCA & water & buffer & EtOH & TCA \\
\hline $\begin{array}{l}\text { (i) } \\
\text { Maximum } \\
\text { absorption } \\
\text { (nm) }\end{array}$ & 352 & 352 & 352 & n.a. & 465 & 465 & 465 & 455 & 560 & 560 & 560 & 560 \\
\hline $\begin{array}{l}\text { (ii) Linearity } \\
\left.\text { (nM H } \mathrm{H}_{2}\right)\end{array}$ & $1-20$ & $1-20$ & $1-60$ & n.a. & $1-80$ & $1-80$ & $10-80$ & n.a. & $1-10$ & n.a. & $1-10$ & $1-10$ \\
\hline $\begin{array}{l}\text { (iii) } \mathrm{H}_{2} \mathrm{O}_{2} \\
\text { recovery } \\
\left.\text { (nM } \mathrm{H}_{2} \mathrm{O}_{2}\right)\end{array}$ & n.a. & n.a. & n.a. & n.a. & n.a. & n.a. & n.a. & n.a. & n.a. & n.a. & $1-20$ & $1-10$ \\
\hline
\end{tabular}

Buffer, $100 \mathrm{mM}$ potassium-phosphate $\mathrm{pH}$ 7.0; DAB, $3.5 \mathrm{mM}$ 3,3'-diaminobenzidine; $\mathrm{EtOH}, 70 \%$ (v/v) ethanol; KI, 1 M potassium-iodide; TCA, $6 \%$ (v/v) trichloroacetic acid: water; XO, $125 \mu \mathrm{M}$ xylenol orange; n.a., not applicable. Raw data are in Figs. S1-S3.

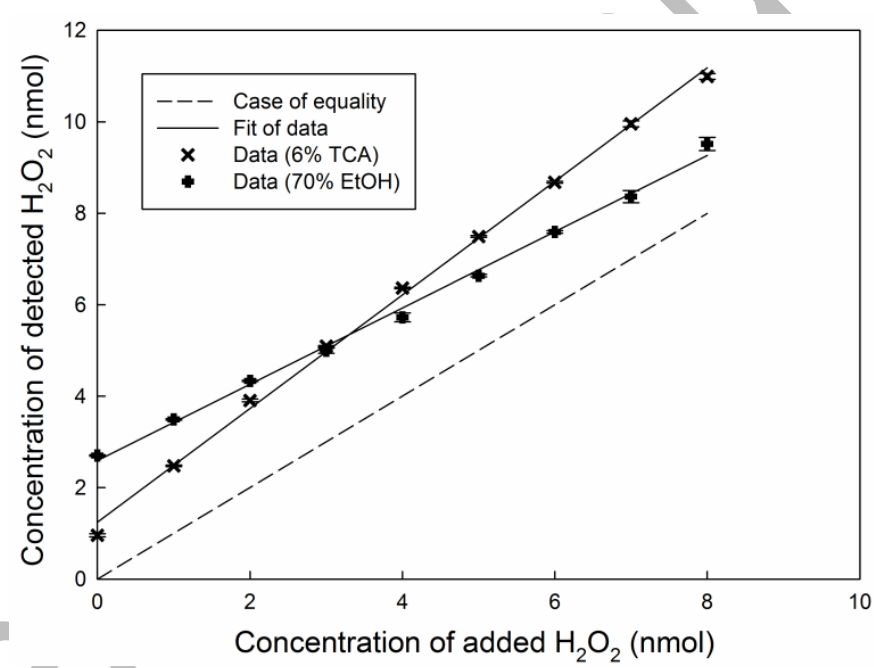

\section{Figure 1.}

Detection of exogenous hydrogen peroxide with xylenol orange in $6 \%(\mathrm{v} / \mathrm{v})$ trichloroacetic acid or $70 \%(\mathrm{v} / \mathrm{v})$ ethanol based leaf extracts. Data represent the mean (marked with $\mathrm{x}$ and + symbols, respectively) and standard deviation of three technical repeats. The dashed line shows the ideal case when the concentration of $\mathrm{H}_{2} \mathrm{O}_{2}$ detected by the assay would be equal to the concentration added. The solid line corresponds to a linear fit of data characterized by $\mathrm{R}^{2}=0.998$ and $\mathrm{R}^{2}=0.996$ coefficients, respectively.

Electronic supplementary information (ESI) available. Figs S1-S5, Table S1.

See DOI: 10.1039/c7ay00126f 